\title{
Dry matter intake observed and predicted by the nutritional systems NRC and BR-Corte for feedlot nelore heifers fed with human feed products
}

\section{Consumo de matéria seca observado e predito pelo NRC e BR-Corte de novilhas nelore em confinamento alimentadas com produtos oriundos da alimentação humana}

\author{
Simone Pedro da Silva ${ }^{1 *}$; Carina Ubirajara de Faria ${ }^{1}$; Ana Caroline Rodrigues \\ da Cunha ${ }^{2}$; Aline Maria Soares Ferreira ${ }^{3}$; Jean Marcos Castro Paula ${ }^{2}$; \\ Ester Ferreira Felipe ${ }^{2}$
}

\begin{abstract}
We aimed to evaluate the effects of using a concentrated ration containing industrialised human food on the productive parameters of Nellore heifers in confinement, in addition to comparing the dry matter intake (DMI) observed with that predicted by the nutritional systems BR-Corte and NRC, in order to determine which system makes the most accurate predictions for heifers of the breed Nelore in feedlots. Twenty-four Nelore heifers, with an average age of 24 months and average body weight (BW) of 350 $\mathrm{kg}$, were used over the 70 days of the experiment. They were randomly assigned to two treatments and housed in partially covered stalls equipped with an automatic Growsafe ${ }^{\circledR}$ Systems feeding system. Animals in the control group (CONT) received a concentrated ration containing ground corn, soybean meal, urea, and mineral nucleus. In the residual treatment (RES) group, heifers received concentrated feed containing products from the human diet. The difference between the treatments was the concentrated ration; in the control treatment, the energy source used was maize, whereas in the residue treatment, the energy sources were corn chips, coconut candies, and ground coffee. Corn silage was included as forage for both treatments. The forage:concentrate $(\mathrm{F}: \mathrm{C})$ ratio was $84: 16$. The predicted intake was estimated according to the nutritional systems NRC $(2000,2016)$ and BR-Corte (VALADARES FILHO et al., 2010, 2016). The average DMI observed of the heifers was $7.46 \mathrm{~kg} \mathrm{day}^{-1}$. Heifers fed with human feed residue had a higher dry matter intake (DMI) and higher ether extract intake (EEI) than animals fed with the control feed. In addition, heifers that received human feed products showed a lower average daily weight gain (DWG) of $1.08 \mathrm{~kg} \mathrm{day}^{-1}$ than animals fed the control treatment with an average DWG of $1.24 \mathrm{~kg} \mathrm{day}^{-1}$. The predicted dry matter intake by NRC 2000 was an overestimate by $9.78 \%$ and by BRCorte 2010 was an overestimate by $5.5 \%$. The NRC 2016 and BR-Corte 2016 underestimated the intake of heifers by $18.9 \%$ and $7.1 \%$, respectively. It was concluded that growing Nelore heifers fed with human feed products, with a F:C ratio of 84:16, present a higher DMI and lower growth performance and feed efficiency than heifers fed the control diet. The DMI predicting models for Nellore heifers proposed by BR-Corte are more adequate than the NRC models.
\end{abstract}

Key words: Beef cattle. Feed efficiency. Models. Nutrition.

${ }^{1}$ Profs. Drs., Universidade Federal de Uberlândia, UFU, Uberlândia, MG, Brasil. E-mail: simone.psilva@hotmail.com; carinauf@ gmail.com

2 Zootecnistas, UFU, Uberlândia, MG, Brasil. E-mail: ana_carolinercunha@yahoo.com.br; jeanmarcosp96@gmail.com; esterferreiraf@live.com

3 Discente, Curso de Doutorado, Programa de Pós-Graduação em Ciências Veterinárias, UFU, Uberlândia, MG, Brasil. E-mail: alinemsferreira@hotmail.com

* Author for correspondence 


\section{Resumo}

Objetivou-se avaliar os efeitos da utilização de ração concentrada contendo produtos industrializados da alimentação humana sobre os parâmetros produtivos de novilhas Nelore em confinamento, além de comparar o consumo de matéria seca observado com o predito pelos sistemas nutricionais BR-Corte e NRC e encontrar qual sistema faz melhores predições para novilhas de corte da raça Nelore em confinamento. Foram utilizadas 24 novilhas da raça Nelore, durante 70 dias de experimento, com idade média de 24 meses e peso corporal (PC) médio de $350 \mathrm{~kg}$, na qual foram distribuídas aleatoriamente em dois tratamentos e alojadas em baias equipadas com sistema automático de alimentação Growsafe ${ }^{\circledR}$. No tratamento controle (CONT), os animais receberam ração concentrada contendo milho moído, farelo de soja, ureia, núcleo mineral. No tratamento resíduo (RES), as novilhas receberam ração concentrada contendo produtos oriundos da alimentação humana. A diferença entre os tratamentos se encontra na ração concentrada, onde no tratamento controle a fonte de energia usada foi o milho, enquanto que no tratamento resíduo, as fontes de energias foram salgadinho de milho, balas de côco e café moído. Silagem de milho foi oferecido como volumoso para ambos os tratamentos, sendo adotado a relação volumoso:concentrado de 84:16. Os consumos preditos foram obtidos utilizando os sistemas nutricionais NRC $(2000,2016)$ e BR-Corte (VALADARES FILHO et al., 2010, 2016). O CMS médio observado nas novilhas foi de $7,46 \mathrm{~kg} \mathrm{dia}^{-1}$. As novilhas alimentadas com ração resíduo tiveram maior consumo de matéria seca (CMS) e maior consumo de extrato etéreo (CEE) em comparação aos animais alimentados com a ração controle. Além disso, os animais que receberam ração resíduo apresentaram menor ganho médio diário (GMD), 1,08 $\mathrm{kg} \mathrm{dia}^{-1} \mathrm{em}$ relação as do tratamento controle com 1,24 kg dia $^{-1}$. A ingestão de matéria seca predita pelo NRC 2000 foi superestimada em 9,78\% e pelo BR-Corte 2010, em 5,5\%, já NRC 2016 e BR-Corte 2016 subestimaram o consumo das novilhas em 18,9\% e $7,1 \%$, respectivamente. Concluiu-se que novilhas Nelore em crescimento alimentadas com ração contendo produtos da alimentação, na relação volumoso:concentrado 84:16 apresentam maior consumo de matéria seca, menor desempenho e eficiência alimentar. Os modelos para predição do CMS para novilhas da raça Nelore propostos pelos sistemas BR-Corte são mais adequados que os modelos do NRC.

Palavras-chave: Bovinos de corte. Eficiência alimentar. Modelos. Nutrição.

\section{Introduction}

Dry matter consumption is the main determinant of animal productivity, and its accurate prediction is essential in the formulation of balanced diets, in order to avoid a deficit or dietary excess of nutrients (CHIZZOTTI et al., 2013). Knowing the daily intake of food by animals is the first step in formulating a diet, since it constitutes the determinant point of nutrient ingress and is necessary to meet the maintenance requirements and for animal production (RIBEIRO et al., 2012). According to Mertens (1994) 60 to $90 \%$ of variations in animal performance can be explained by consumption and only 10 to $40 \%$ by effects attributed to the nutritional value of the food, such as the digestibility. In other words, when seeking to maximise animal performance, it is necessary to know the food consumption of the animals, which is an extremely difficult variable to estimate through mathematical models, since there are innumerable factors that affect it.

Despite the complexity of generating empirical equations to estimate consumption, nutritional systems such as the National Research Council (NRC), Agricultural and Food Research Council (AFRC), Cornell Net Carbohydrate and Protein System (CNCPS), and BR-Corte have worked to hone these equations. It is important to emphasise that the American and British systems developed equations to predict consumption using predominantly Bos taurus as database animals, whereas in Brazil, the BR-Corte system developed by researchers from the Universidade Federal de Viçosa (UFV) developed models to estimate consumption in zebu cattle and crossbreeds. 
Some studies were carried out in Brazil to quantify the consumption of food by Bos taurus, Bos indicus animals and their crossbreed (MARCONDES et al., 2008; MACHADO NETO et al., 2011; RIBEIRO et al., 2012). A difference in the food consumption by taurine and zebu animals kept in confinement was evidenced by Almeida and Lanna (2003) and Machado Neto et al. (2011), who found lower values of consumption by zebu than taurine animals. Thus, it is important to verify within each system of beef cattle production which nutritional system makes the most accurate and precise predictions of consumption. Then, it will be possible to use the chosen model in different software calculations of rations, as well as in planning and purchasing food in production systems. Therefore, studies are necessary to validate these equations with the aim of identifying which models are able to most accurately predict consumption by beef cattle.

The concentrated ration represents approximately 70 to $80 \%$ of the feed cost of feedlot beef cattle (ARRIGONI et al., 2013) and is one of the biggest bottlenecks in production systems. Therefore, the use of products derived from human food becomes an interesting strategy when it is aimed at minimising expenses with variable costs arising from the use of corn, soybean, millet, cotton, sorghum, and other foods with high market value (CRUZ et al., 2013).

According to the United Nations for Agriculture and Food, Brazil suffers large losses in supermarkets due to products that are out of date, poorly packed, or wasted, corresponding to approximately $30 \%$ of all world production, which is equivalent to 1.3 billion tons of food and accounts for more than half of the world's cereal grain production. Approximately 2.3 million tons of food a year go to waste, generating economic damage of approximately $\mathrm{R} \$ 3$ trillion per year, which consequently affects the quality, quantity, and price of food for the human consumer market (FREITAS, 2014). Faced with this waste, it is important to note that some of these foods unfit for human consumption could be used in animal nutrition, such as pasta, coconut candies, corn chips, coffee, fruit pulps, potatoes, and others.

In addition to avoiding the waste in the human food industry, the use of these residues can be a good alternative in cattle feed to meet the nutritional requirements of the animals; such foods can be used instead of the protein and energy sources that are routinely used in ruminant rations, with the objective to reduce the expenditure on animal feed. Some of these products of human food are distinguished by their chemical composition, digestibility, market value, availability, and ease at the moment of offering to the animals, since the main obstacle would be opening the packaging, which could cause aluminium contamination of the products (ROGÉRIO et al., 2009), as well as the high sodium content of these foods. However, few studies have been carried out to verify their nutritional composition, as well as the potential for the production of cattle fed these products.

We therefore aimed to evaluate the effects of using a concentrated ration containing industrialised food products on the productive parameters of Nellore heifers in confinement, in addition to comparing the observed dry matter intake with that predicted by the nutritional systems BR-Corte and NRC to determine which system makes better predictions for Nellore breed heifers in feedlots.

\section{Material and Methods}

The experiment was carried out at Capim Branco Experimental Farm of Faculty of Veterinary Medicine (FAMEV), Federal University of Uberlândia (UFU), Uberlândia, Minas Gerais, Brazil, from November 2016 to January 2017, totalling 70 days of experiment and 14 days of adaptation. Twenty-four Nelore heifers, with a mean age of 24 months and mean body weight (BW) of $350 \mathrm{~kg}$, were used. These animals remained in pickets with pastures of Brachiaria brizantha $\mathrm{cv}$. Marandú and protein supplement offered at $0.1 \%$ BW before entering confinement. 
The heifers were randomly allocated into two treatments. In the control treatment (CONT), the animals received a concentrated ration containing ground corn, soybean meal, urea, and mineral nucleus. In the residual treatment (RES), the heifers received a concentrated ration containing products from the human diet. The difference between the treatments was in the concentrated ration; in the control treatment, the energy source used was corn, whereas in the residue treatment, the energy sources were corn chips, coconut candies, and ground coffee. Corn silage was offered as forage for both treatments, in the forage:concentrate ratio of 84:16. The rations were formulated to meet the nutritional requirements of growing Nellore heifers with a weight gain of $700 \mathrm{~g}$ day $^{-1}$, according to BR-Corte (VALADARES FILHO et al., 2016).

The heifers were housed in two partially covered stalls equipped with a Growsafe ${ }^{\circledR}$ automated feeding system (Growsafe Systems Ltd., Airdrie, Alberta, Canada) to measure the individual intake of the animals. In this feeding system, each stalls has four troughs arranged side by side. Before the beginning of the experimental period, the animals were identified with electronic earrings that identified when the animals accessed the electronic troughs, measuring the individual food intake for $24 \mathrm{~h}$.

The feed was given ad libitum twice a day at $08 \mathrm{~h} 00$ and $16 \mathrm{~h} 00$, allowing for leftovers of 5 to $10 \%$ of the daily offering. Daily, in the morning, the leftovers in the troughs were collected and weighed to monitor the intake of food and to make adjustments to the amount of food offered to the animals. After collection, the leftovers samples were stored in a freezer for further analysis of their chemical-bromatological composition.

The variables measured were dry matter and nutrient intake, average daily weight gain, feed conversion ratio, and feed efficiency. The animals were weighed after fasting from food for $16 \mathrm{~h}$ at the beginning and end of the experiment. The samples of leftovers and offered rations were analysed to determine the nutrient intake according to the methodology described by Detmann et al. (2012).

The completely randomised design (CRD) with two treatments and twelve replicates was used to compare the different rations, and an F-test was performed on the means adopting a $5 \%$ level of significance.

Subsequently, the prediction equations for the dry matter intake according to the nutritional systems NRC 2000 (NRC, 2000), NRC 2016 (NRC, 2016), BR-Corte 2010 (VALADARES FILHO et al., 2010), and BR-Corte 2016 (VALADARES FILHO et al., 2016) were evaluated and these estimates were compared to the observed dry matter intake, determined during the experiment using the electronic feeding system.

The following equation was used to determine the dry matter intake predicted by the NRC (2000) system:

$$
\mathrm{DMI}=\left(\mathrm{SBW}^{0.75} *(0.2435 \mathrm{NEm}(\text { diet })-0.0466\right.
$$

NEm(diet) 2 - 0.0869) / NEm(diet) * Correction factor

(Table 10-4, NRC, 2000)

where, SBW: shrunk body weight; NEm: net energy for maintenance of diet.

In order to obtain the net energy estimate of the diet, the crude energy was first determined using a calorimetric bomb, after which it was transformed into digestible energy, assuming $1 \mathrm{~kg}$ Total Digestible Nutrients (TDN) equals 4409 Mcal of digestible energy. To convert the digestible energy into metabolisable energy, the factor 0.82 (NRC, 2016) was used and the equations proposed by Fox et al. (1972) were used to obtain the net energy of maintenance and gain (NRC, 2016):

$\mathrm{NEm}=1.37 * \mathrm{ME}-0.138 * \mathrm{ME}^{2}+0.0105 * \mathrm{ME}^{3}-1.12$
$\mathrm{NEg}=1.42 * \mathrm{ME}-0.174 * \mathrm{ME}^{2}+0.0122 * \mathrm{ME}^{3}-1.65$

where, NEm: net energy for maintenance; NEg: net energy for gain; and ME: metabolisable energy. 
The following equation was used to calculate the dry matter intake required according to the NRC (2016) system:

DMIR $\left(\mathrm{kg} \mathrm{day}^{-1}\right)=\mathrm{NEm}$ required $\left(\mathrm{Mcal} \mathrm{day}^{-1}\right) /$ $\mathrm{NEm}$ diet $($ Mcal kg-1 dietary DM) $+\mathrm{NEg}$ required $\left(\right.$ Mcal day $\left.{ }^{-1}\right) / \mathrm{NEg} \operatorname{diet}\left(\mathrm{Mcal} \mathrm{kg}^{-1}\right.$ dietary DM)

NEm required: $0.0077 * \mathrm{SBW}^{0.75}$;

NEg required: $0.0635 * \mathrm{EBW}^{0.75 *} \mathrm{EBG}^{1.097}$, where: $\mathrm{EBW}=0.891 * \mathrm{SBW}$, and $\mathrm{EBG}=0.956 * \mathrm{ADG}$.

For determination of the dry matter intake predicted by the BR-Corte system (VALADARES FILHO et al., 2010), the following model was adopted:

DMI $\left(\mathrm{kg} \mathrm{day}^{-1}\right)=-2.7878+0.08789 * \mathrm{BW}^{0.75}+$

$$
5.0487 * \mathrm{ADG}-1.6835 * \mathrm{ADG}^{2}
$$

where, BW: body weight; ADG: average daily gain.

The following model was used to calculate the dry matter intake predicted by the BR-Corte system (VALADARES FILHO et al., 2016):

DMI $\left(\mathrm{kg} \mathrm{day}^{-1}\right)=-1.303+0.0029 * \mathrm{CL}-0.00005 *$ $\mathrm{CL}^{2}+0.0843 * \mathrm{BW}^{0.75}+2.243 * \mathrm{ADG}-0.271 * \mathrm{ADG}^{2}$

where, CL: concentrate level in the diet (\% total diet DM); BW: body weight; ADG: average daily gain.

The accuracy of the estimates of dry matter intake by the nutritional systems was adjusted by the simple linear regression model of the observed values over the predicted values and the statistical tests were conducted under the following hypotheses: $\mathrm{H} 0:{ }_{\beta} 0=0$ and $_{\beta} 1=1$ and $\mathrm{H} 1$ : $\operatorname{not} \mathrm{H} 0$.

The null hypothesis was not rejected when the predicted and observed values were similar, shown by plotting the predicted values on the $\mathrm{X}$ axis and the observed values on the $\mathrm{Y}$ axis, as recommended by Tedeschi (2006). A comparative evaluation of the prediction efficiency among the nutritional systems was carried out by the evaluation and decomposition of the mean square error of prediction (MSEP), according to the protocols described by Kobayashi and Salam (2000).

The MSEP was also verified in the case of rejection of the null hypothesis, making it possible to infer the proximity of the predicted values and the observed values.

\section{Results and Discussion}

The chemical-bromatological composition of the control ration (CONT) and the residual ration (RES) is presented in Table 1. It was verified that the diets were very similar in relation to dry matter, mineral matter, crude protein, neutral detergent insoluble fibre, non-fibrous carbohydrates, digestible energy, calcium, and phosphorus, and only the content of ethereal extract differed between the diets, with the residual diet containing more fat than the control diet, which might be a consequence of the presence of products derived from human food, such as corn chips, candies, and sweets with a higher fat content.

There was no effect of the control and residue ration on the dry matter intake, and the intake of organic matter, neutral detergent insoluble fiber, and non-fibrous carbohydrates $(\mathrm{P}>0.05)$. Heifers fed the residual diet had a higher consumption of ethereal extract (EE) and crude protein (CP), expressed in kilogrammes per day, than the animals that received the control diet $(\mathrm{P}<0.05$; Table 2$)$, reflecting the higher concentration of these nutrients in the residue diet due the presence of foods from human diets. 
Table 1. Chemical-bromatological composition of the control ration (CONT) and residue ration (RES).

\begin{tabular}{|c|c|c|c|c|c|c|c|c|c|c|}
\hline & $\begin{array}{l}\mathrm{DM} \\
(\%)\end{array}$ & $\begin{array}{l}\text { NM } \\
(\%)\end{array}$ & $\begin{array}{l}\mathrm{CP} \\
(\%)\end{array}$ & $\begin{array}{l}\mathrm{EE} \\
(\%)\end{array}$ & $\begin{array}{l}\text { NDF } \\
(\%)\end{array}$ & $\begin{array}{l}\text { NFC } \\
(\%)\end{array}$ & $\begin{array}{l}\mathrm{Ca} \\
(\%)\end{array}$ & $\begin{array}{c}\mathrm{P} \\
(\%)\end{array}$ & $\begin{array}{l}\text { TDN } \\
(\%)\end{array}$ & $\begin{array}{c}\mathrm{DE} \\
\left(\mathrm{Mcal} \mathrm{kg}^{-1}\right)\end{array}$ \\
\hline Ration CONT & 40.8 & 3.2 & 10.9 & 3.3 & 41.1 & 40.4 & 0.4 & 0.3 & 67.20 & 2.96 \\
\hline Ration RES & 41 & 3.2 & 10.1 & 4.1 & 42.8 & 39.7 & 0.5 & 0.3 & 67.72 & 2.99 \\
\hline
\end{tabular}

$\mathrm{DM}=$ dry matter; $\mathrm{NM}=$ natural material; $\mathrm{NDF}=$ neutral detergent fibre; $\mathrm{CP}=$ crude protein; $\mathrm{EE}=$ ether extract; $\mathrm{NFC}=$ non-fibrous carbohydrate; TDN = total digestible nutrients; $\mathrm{Ca}=$ calcium; $\mathrm{P}=$ phosphorus; $\mathrm{DE}=$ digestible energy.

Table 2. Nutrient intake in heifers fed with control ration and residue.

\begin{tabular}{lccccc}
\hline \multicolumn{1}{c}{ Items } & Control Ration & Residue Ration & Mean & Standard Deviation & $P$ Value \\
\hline DMI $\left(\mathrm{kg} \mathrm{day}^{-1}\right)$ & 7.67 & 7.26 & 7.46 & 0.95 & 0.29 \\
${\text { OMI }\left(\mathrm{kg} \mathrm{day}^{-1}\right)}$ NDFI $\left(\mathrm{kg} \mathrm{day}^{-1}\right)$ & 3.42 & 7.01 & 7.21 & 0.92 & 0.27 \\
CPI $\left(\mathrm{kg} \mathrm{day}^{-1}\right)$ & $0.84 \mathrm{a}$ & 3.11 & 3.13 & 0.39 & 0.79 \\
EEI $\left(\mathrm{kg} \mathrm{day}^{-1}\right)$ & $0.25 \mathrm{~b}$ & $0.73 \mathrm{~b}$ & 0.78 & 0.11 & 0.02 \\
DMI $(\% \mathrm{BW})$ & 2.22 & $2.29^{\mathrm{a}}$ & 0.27 & 0.04 & $<0.01$ \\
NDFI $(\% \mathrm{BW})$ & 0.91 & 0.89 & 2.15 & 0.21 & 0.12 \\
\hline
\end{tabular}

DMI: dry matter intake; OMI: organic matter intake; NDFI: neutral detergent fibre intake; CPI: crude protein intake; EEI: ether extract of intake.

The average dry matter intake by heifers was $7.46 \mathrm{~kg} \mathrm{day}^{-1}$ (Table 2), and this value was close to the values proposed by Valadares Filho et al. (2016) in the nutritional requirements tables of BR-Corte 3.0, who verified an average DMI of $6.89 \mathrm{~kg}^{-}$day ${ }^{1}$ and a maximum DMI of $7.58 \mathrm{~kg} \mathrm{day}^{-1}$ for zebu heifers in confinement, with an average initial body weight of $300 \mathrm{~kg}$, final body weight of $400 \mathrm{~kg}$, and average daily weight gain of $0.7 \mathrm{~kg} \mathrm{day}^{-1}$.

The heifers fed the residual ration had a lower DWG $\left(1.08 \mathrm{~kg} \mathrm{day}^{-1}\right)$ than the animals fed the control ration $\left(1.24 \mathrm{~kg} \mathrm{day}^{-1}\right)(\mathrm{P}<0.05$; Table 3). Regarding food efficiency, there was no statistical difference between the treatments $(\mathrm{P}>0.05$; Table 3 ). The lower performance of heifers fed with the residual ration might be due to the lower digestible energy consumption presented by this diet than the control ration. It is likely that the replacement of ground corn in control rations with foods from human diets, such as corn chips, coconut candies, and ground coffee as energy source, did not fully meet the energy demand of these animals in confinement, which resulted in lower average daily weight gain.

According to the BR-Corte system (VALADARES FILHO et al., 2016) the crude protein requirement for zebu heifers with an average body weight of $315 \mathrm{~kg}$ and for an average daily weight gain of $1.1 \mathrm{~kg} \mathrm{day}^{-1}$ is $0.858 \mathrm{~kg} \mathrm{day}^{-1}$, which shows that the animals that received the residual ration had a protein consumption below the requirement and, therefore, presented lower performance.

Table 3. Average daily weight gain and feed efficiency in heifers fed control ration and residue.

\begin{tabular}{lccccc}
\hline \multicolumn{1}{c}{ Items } & Control Ration & Residue Ration & Mean & Standard Deviation & $P$ Value \\
\hline DWG $\left(\mathrm{kg} \mathrm{day}^{-1}\right)$ & $1.24 \mathrm{a}$ & $1.08 \mathrm{~b}$ & 1.16 & 0.15 & $<0.01$ \\
$\mathrm{FE}\left(\mathrm{kg} \mathrm{gain} \mathrm{kg} \mathrm{DMI}^{-1}\right)$ & 0.16 & 0.15 & 0.15 & 0.023 & 0.25 \\
\hline
\end{tabular}

$\mathrm{DWG}=$ average daily weight gain; $\mathrm{FE}=$ feed efficiency. 
Other studies are needed to verify the effect of feed containing products from human diets on the production costs in confinement, in order to verify whether, despite the lower performance of animals fed with these products, it would be possible for the animals to spend more days in the feedlot with a lower cost feed.

In order to compare the dry matter intake observed with that predicted by the nutritional systems BR-Corte and NRC, and to determine which system makes better predictions of dry matter intake for Nelore beef cattle, the hypotheses of the intercept (a) being equal to zero and the slope (b) being equal to one were tested, according to Neter et al. (1996). In the case of NRC (2016), the null hypothesis was rejected ( $\mathrm{P}<0.01$; Table 4$)$, which means that the predicted values were significantly different to the observed values. However, for the NRC (2000) and Br-Corte (2010 and 2016) systems, the null hypotheses were not rejected (P $>0.05$; Table 4), therefore, the values predicted by these systems were equal to the values observed, indicating that the models used to estimate the DMI by the NRC (2000) and Br-Corte (2010 and 2016) systems tended to be parallel to the $Y=X$ line and were able to explain 41,51 , and $48 \%$ of the variation, respectively $\left(\mathrm{R}^{2}=0.41,0.51\right.$, and 0.47$)$.

Table 4. Regression analysis of the values of dry matter intake (DMI) observed and predicted by the NRC (2000 and 2016) and BR-Corte (2010 and 2016) systems.

\begin{tabular}{lcccccc}
\hline \multicolumn{1}{c}{ System } & $\mathrm{R}^{2} \mathrm{a}$ & $\mathrm{A}$ & $\mathrm{B}$ & $\mathrm{SEM}$ & $\begin{array}{c}P^{l} \text { Value } \\
(\text { Ho: } \mathrm{a}=0)\end{array}$ & $\begin{array}{c}P^{2} \text { Value } \\
(\text { Ho: } \mathrm{b}=1)\end{array}$ \\
\hline NRC 2000 & 0.413 & -1.761 & 1.126 & 0.534 & 0.428 & 0.641 \\
NRC 2016 & 0.288 & 4.289 & 0.523 & 0.648 & $<0.001$ & $<0.001$ \\
BR-Corte 2010 & 0.518 & 2.720 & 1.292 & 0.438 & 0.18 & 0.25 \\
BR-Corte 2016 & 0.478 & 0.496 & 1.005 & 0.474 & 0.73 & 0.97 \\
\hline
\end{tabular}

$\mathrm{R}^{2} \mathrm{a}=$ adjusted correlation coefficient; $\mathrm{A}=$ intercept; $\mathrm{B}=$ slope; $\mathrm{SEM}=$ standard error of the mean.

The values predicted by the models were plotted on the $\mathrm{X}$ axis and the observed values were plotted on the $\mathrm{Y}$ axis, since the observed values contain variability, whereas the values predicted by the model are deterministic, without random variation (HARRISON, 1990; MAYER; BUTLER, 1993; MAYER et al., 1994; TEDESCHI, 2006). In this graph format, data points below and above the $\mathrm{Y}$ $=\mathrm{X}$ line indicate low accuracy of the mathematical model.

The dry matter intake predicted by NRC (2000) for heifers was overestimated by $9.78 \%$ and by BR-Corte (VALADARES FILHO et al., 2010) by $5.5 \%$. The NRC 2016 and Br-Corte 2016 models underestimated the dry matter intake of heifers by $18.9 \%$ and $7.1 \%$, respectively (Table 5).
The regression estimate of the coefficient of determination $\left(\mathrm{R}^{2}\right)$ is a good indicator of the precision of model; the higher the $\mathrm{R}^{2}$, the higher the precision. In this case, the models for predicting the dry matter intake by the NRC 2000 and 2016 had the smallest $\mathrm{R}^{2}$ (Table 4 ). The precision of the model is considered one of the most important measures since it measures the model's ability to predict true values (TEDESCHI, 2006). However, the interpretation of the coefficient of determination $\left(\mathrm{R}^{2}\right)$ requires care, since a high value of $\mathrm{R}^{2}$ does not indicate that valid predictions can be obtained by a given mathematical model, since this coefficient measures the precision and not the accuracy of the model. In addition, a high correlation coefficient value does not imply that the regression model is well adjusted, since the relationship between the 
observed and predicted values might be curvilinear. Furthermore, values of $\mathrm{R}^{2}$ close to zero do not indicate that the observed and predicted values are not correlated, since they might have a curvilinear relationship (TEDESCHI, 2006).

Table 5. Minimum, mean, and maximum dry matter intake observed and predicted $\left(\mathrm{kg} \mathrm{day}^{-1}\right)$ by the nutritional NRC (2000 and 2016) and BR-Corte (2010 and 2016) systems.

\begin{tabular}{lcccccc}
\hline & & \multicolumn{5}{c}{ Predicted } \\
\hline & Observed & $\mathrm{N}$ & NRC 2000 & NRC 2016 & BR Corte 2010 & BR Corte 2016 \\
\hline Minimum & 5.95 & 25 & 7.25 & 4.61 & 7.01 & 5.89 \\
Mean & 7.46 & 25 & 8.19 & 6.05 & 7.87 & 6.92 \\
Maximum & 9.53 & 25 & 9.68 & 8.17 & 9.30 & 8.53 \\
\hline
\end{tabular}

Therefore, the comparison between the values observed and those predicted by mathematical models should be performed by the analysis of the mean square error of the prediction (MSEP) (TEDESCHI, 2006). According to the results obtained after analysis of the MSEP and its components, the BR-Corte 2010 and 2016 systems presented predicted values closer to those observed than those predicted by the NRC 2000 and 2016, since the BR-Corte models presented lower values of mean deviation and systematic deviation (Table 6). Considering the regression analysis (Table 4) and the MSEP analysis (Table 6), the BR-Corte 2010 and 2016 systems were more efficient at predicting dry matter intake than the NRC 2000 and 2016 systems.

Table 6. Analysis of the mean square error of prediction (MSEP) and it's decomposition.

\begin{tabular}{lcccc}
\hline & \multicolumn{3}{c}{ System } \\
\hline & NRC 2000 & NRC 2016 & BR-Corte 2010 & BR-Corte 2016 \\
\hline MSEP & 1.03 & 2.79 & 0.59 & 0.72 \\
\hline Variance of the MSEP & 1.18 & 3.25 & 0.52 & 0.62 \\
\hline Standard Deviation of the MSEP & 1.09 & 1.80 & 0.72 & 0.79 \\
\hline Coefficient of variation of the MSEP (\%) & 105.69 & 64.46 & 120.69 & 109.92 \\
\hline Square root of the MSEP & 1.01 & 1.67 & 0.77 & 0.84 \\
\hline & \multicolumn{4}{c}{ Decomposition of MSEP (\%) } \\
\hline Mean deviation & 51.74 & 70.43 & 28.61 & 39.41 \\
\hline Systematic deviation & 0.46 & 8.24 & 4.03 & 0.02 \\
\hline Random errors & 47.79 & 21.32 & 67.35 & 60.58 \\
\hline
\end{tabular}

Valadares Filho et al. (2006) also found a lack of adjustment for the models proposed by the NRC in predicting the dry matter intake of beef cattle under tropical conditions. The models proposed by the Br-Corte (2010 and 2016) systems are better able to estimate DMI in Nellore heifers, since they were developed with a database of Bos indicus cattle fed with tropical forages. In addition, the equations proposed by BR-Corte are easier to use since they only require information on body weight (BW), average daily gain (ADG), and in the case of equations proposed by BR-Corte 2016, the level of concentrate (CL) in the diet, all of which are quickly obtainable. However, the models proposed by the NRC involve the use of information about the net energy of the diet and that required for the animal, which demands greater efforts to obtain. 


\section{Conclusions}

Growing Nellore heifers fed with ration containing products of human food in the ratio $84: 16$ forage:concentrate present dry matter intake and feed efficiency similar to the animals fed the control ration, however, they have a lower performance.

The models for predicting dry matter intake in beef cattle proposed by the BR-Corte 2010 and 2016 systems are better than the NRC 2000 and 2016 models.

\section{References}

ALMEIDA, R.; LANNA, D. P. D. Influence of genotype on performance and dry matter intake by feedlot steers in Brazil. In: WORLD CONFERENCE ON ANIMAL PRODUCTION; REUNIÃO DA ASSOCIAÇÃO LATINOAMERICANA DE PRODUÇÃO ANIMAL, 9., 18., 2003, Porto Alegre. Proceedings... Porto Alegre: Associação Latino Americana de Produção Animal, 2003. p. 84.

ARRIGONI, M. B.; MARTINS, C. L.; SARTI, L. M. N.; BARDUCCI, R. S.; FRANZÓI, M. C. S.; VIEIRA JÚNIOR, L. C.; PERDIGÃO, A.; RIBEIRO, F. A.; FACTORI, M. A. Níveis elevados de concentrado na dieta de bovinos em confinamento. Revista Veterinária e Zootecnia, Botucatu, v. 20, n. 4, p. 539-551, 2013. Disponível em: http://hdl.handle.net/11449/141034. Acesso em: 7 aug. 2017.

CHIZZOTTI, M. L.; VALENTE, E. E. L.; GOMES, R. A.; CHIZOTTI, F. H. M.; LADEIRA, M. M.; RODRIGUES, R. T. S. Modelagem para a predição de consumo de ruminantes. In: SIMPÓSIO DE PRODUÇÃO DE RUMINANTES NO CERRADO: INOVAÇÕES TECNOLÓGICAS, 2., 2013, Uberlândia. Anais... Uberlândia: FAMEV-UFU, 2013. p. 259-292.

CRUZ, S. S.; MORAIS, A. B. F.; RIBEIRO, S. B.; OLIVEIRA, M. G.; COSTA, M. S.; FEITOSA, C. T. L. Resíduos de frutas na alimentação de ruminantes. Revista Eletrônica Nutritime, Viçosa, MG, v. 10, n. 6, p. 29092931, 2013. Disponível em: http://www.nutritime.com. br/arquivos_internos/artigos/Artigo 222.pdf. Acesso em: 7 aug. 2017.

DETMANN, E.; SOUZA, M. A.; VALADARES FILHO, S. C.; QUEIROZ, A. C.; BERCHIELLI, T. T.; SALIBA, E. O. S.; CABRAL, L. S.; PINA, D. S.; LADEIRA, M. M.; AZEVEDO, J. A. G. Métodos para análise de alimentos - INCT - Ciência Animal. Visconde do Rio Branco: Suprema, 2012. 214 p.

FOX, D. J.; JOHNSON, R. R.; PRESTON, R. L.; DOCKERTY, T. R.; KLOSTERMAN, E. W. Protein and energy utilization during compensatory growth in beef cattle. Journal of Animal Science, Champaign, v. 34, n. 2 , p. $310-318,1972$. DOI: $10.2527 /$ jas1972.342310x

FREITAS, T. Mercado desperdiça 30\% dos alimentos perdidos. São Paulo: Folha de São Paulo, 2014. 1 p. Disponível em: http://www1.folha.uol.com.br/ mercado/2014/07/1488819-mundo-desperdica-30-dosalimentos-produzidos.shtml. Acesso em: 26 maio 2019.

HARRISON, S. R. Regression of a model on real-system output: an invalid test of model validity. Agricultural Systems, Örebro, v. 34, n. 3, p. 183-190, 1990. DOI: 10.1016/0308-521X(90)90083-3

KOBAYASHI, K.; SALAM, M. U. Comparing simulated and measured values using mean squared deviation and its components. Agronomy Journal, Madison, v. 92, n. 2, p. $345-352$, 2000. DOI: $10.1007 / \mathrm{s} 100870050043$

MACHADO NETO, O. R.; LADEIRA, M. M.; GONÇALVES, T. M.; LOPES, L. S.; OLIVEIRA, D. M.; LIMA, R. R. Performance and carcass traits of Nellore and Red Norte steers finished in feedlot. Revista Brasileira de Zootecnia, Viçosa, MG, v. 40, n. 5, p. 10801087, 2011. Disponível em: http://dx.doi.org/ 10.1590/ S1516-35982011000500020. Acesso em: 26 mar. 2017. DOI: $10.1590 / \mathrm{S} 1516-35982011000500020$

MARCONDES, M. I.; VALADARES FILHO, S. C.; PAULINO, P. V. R.; DETMANN, E.; PAULINO, M. F.; DINIZ, L. L.; SANTOS, T. R. Consumo de desempenho de animais alimentados individualmente ou em grupo e características de carcaça de animais Nelore de três classes sexuais. Revista Brasileira de Zootecnia, Viçosa, MG, v. 37, n. 12, p. 2243-2250, 2008. DOI: $10.1590 /$ S1516-35982008001200023

MAYER, D. G.; BUTLER, D. G. Statistical validation. Ecological Modelling, Towson, v. 68, n. 1, p. 21-32, 1993. DOI: $10.1016 / 0304-3800(93) 90105-2$

MAYER, D. G.; STUART, M. A.; SWAIN, A. J. Regression of real-world data on model output: an appropriate overall test of validity. Agricultural Systems, Örebro, v. 45, n. 1, p. 93-104, 1994. DOI: 10.1016/ S0308-521X(94)90282-8

MERTENS, D. R. Regulation of forage intake. In: FAHEY JUNIOR, G. C.; COLLINS, M.; MERTENS, D. R.; MOSER, L. E. (Ed.). Forage quality, evaluation and utilization. Madison: American Society of Agronomy, Crop Science of America, Soil Science of America, 1994. p. 450-493. 
NATIONAL RESEARCH COUNCIL - NRC. Nutrient requirements of beef cattle. $7^{\text {th }}$ ed. rev. Washington: DC, 2000. $234 \mathrm{p}$.

NATIONAL RESEARCH COUNCIL - NRC. Nutrient requirements of beef cattle. $8^{\text {th }}$ ed. rev. Washington: DC, 2016. $494 \mathrm{p}$.

NETER, J.; KUTNER, M. H.; NACHTSHEIM, C. J.; WASSERMAN, W. Applied linear statistical models. $4^{\text {th }}$ ed. New York: McGraw-Hill, 1996. 1408 p.

RIBEIRO, J. S.; LADEIRA, M. M.; MACHADO NETO, O. R.; CAMPOS, F. R. Consumo alimentar e sua predição pelos sistemas NRC, CNCPS e BR-CORTE, para tourinhos zebuínos confinados. Revista Ciência Agronômica, Fortaleza, v. 43, n. 4, p. 802-810, out./dez. 2012. Disponível em: http://www.ccarevista.ufc.br/ seer/ index.php/ccarevista/article/view/1768/764. Acesso em: 26 mar. 2017.

ROGÉRIO, M. C. P.; ARAÚJO, G. G. L.; ALVES, M. J.; NEIVA, J. N. M.; COSTA, H. H. A. Resíduos de frutas na alimentação de gado de leite. In: GONÇALVES, L. C.; BORGES, I.; FERREIRA, P. D. S. Alimentos para gado de leite. Belo Horizonte: FEPMVZ, 2009. cap. 6, p. 88-115.
TEDESCHI, L. O. Review Assessment of the adequacy of mathematical models. Agricultural Systems, Örebro, v. 89, n. 2, p. 225-247, 2006. DOI: 10.1016/j. agsy.2005.11.004

VALADARES FILHO, S. C.; COSTA E SILVA, L. F.; LOPES, S. A. GIONBELLI, M. P.; ROTTA, P. P.; MARCONDES, M. I.; CHIZZOTTI, M. L.; PRADOS, L. F. BR-CORTE 3.0. Cálculo de exigências nutricionais, formulação de dietas e predição de desempenho de zebuínos puros e cruzados. Viçosa, MG: UFV, 2016. 327 p. Disponível em: http://www.brcorte.com.br. Acesso em: 24 mar. 2017.

VALADARES FILHO, S. C.; MARCONDES, M. I.; CHIZZOTTI, M. L.; PAULINO, P. V. R. Exigências nutricionais de zebuinos puros e cruzados BR-CORTE. $7^{\text {th }}$ ed. Viçosa, MG: UFV, 2010. 193 p.

VALADARES FILHO, S. C.; PAULINO, P. V. R.; MAGALHÃES, K. A. Exigências nutricionais de zebuínos e tabelas de composição de alimentos BRCorte. Viçosa, MG: UFV, 2006. 142 p. 